\title{
Pengembangan Instrumen Four-Tier Test Berbasis Website pada Materi Rangkaian Listrik di Perguruan Tinggi
}

\author{
Teana Nisa Ekacitra ${ }^{(1)}$, Maison ${ }^{(2)}$, Wawan Kurniawan ${ }^{(3)}$ \\ 1, 2, 3 Program Studi Pendidikan Fisika, Jurusan Pendidikan MIPA \\ Fakultas Keguruan dan IImu Pendidikan Universitas Jambi, Indonesia \\ Email: ${ }^{1}$ teananec@gmail.com , ${ }^{2}$ maison@unja.ac.id, \\ ${ }^{3}$ kurniawan wawan@unja.ac.id
}

\begin{abstract}
Abstrak: Penelitian ini merupakan penelitian pengembangan yang bertujuan: (1) untuk mengembangkan instrumen miskonsepsi mahasiswa Pendidikan Fisika berbasis web pada materi Rangkaian Listrik, (2) untuk mengetahui kelayakan hasil pengembangan miskonsepsi mahasiswa Pendidikan Fisika berbasis web pada materi Rangkaian Listrik. Penelitian ini menggunakan model ADDIE. Tahapan ADDIE terdiri dari Analysis, Design, Development, Implementation, Evaluation. Hasil validasi ahli media menunjukkan bahwa instrumen sangat layak untuk digunakan dengan rata-rata persentase kelayakan setiap aspek adalah $92,67 \%$. Instrumen yang telah dikembangakan dapat digunakan secara luas dan meminimalkan waktu yang digunakan dalam mengidentifikasi miskonsepsi.

\begin{tabular}{l}
\hline Tersedia Online di \\
\hline http://journal.unublitar.ac.id/pendidi \\
kan/index.php/Riset_Konseptual \\
\hline Sejarah Artikel \\
\hline Diterima pada : $20-04-2021$ \\
Disetuji pada : 27-04-2021 \\
Dipublikasikan pada : $30-04-2021$ \\
\hline Kata Kunci: \\
\hline Pengembangan, miskonsepsi, web \\
\hline DOI: \\
http://doi.org/10.28926/riset_konseptual.v5i \\
\hline
\end{tabular}

Tersedia Online di

http://journal.unublitar.ac.id/pendidi

kan/index.php/Riset_Konseptual

Diterima pada : 20-04-2021

Disetuji pada : 27-04-2021

Dipublikasikan pada : 30-04-2021
\end{abstract}

PENDAHULUAN

Tahun 2020 perkembangan industri telah pada tahap revolusi industry 4.0 (Utomo, 2019). Pada tahap ini segala hal dirancang untuk dapat saling berkomunikasi menggunakan teknologi loT (Internet of Things). Revolusi ini juga mempengaruhi bidang Pendidikan. Pendidikan manusia digolongkan menjadi tiga, yakni: pendidikan informal, pendidikan formal, pendidikan nonformal (Hilma et al., 2017). Salah satu bentuk pendidikan formal adalah Perguruan Tinggi yang diharapkan dapat menyiapkan lulusan yang berkualitas serta mampu bersaing, menguasai perkembangan teknologi dan adatif terhadap perkembangan jaman (Subekti et al., 2017). Melalui sistem komunikasi dan interaksi antara guru dengan siswa yang intensif pada pendidikan, akan menciptakan proses pembelajaran yang efektif (Inah, 2015). Salah satu kendala yang muncul dalam proses pembelajaran adalah rendahnya pengusaan konsep mahasiswa yang diakibatkan adanya miskonsepsi pada mahasiswa (Fitria, 2014).

Dalam proses pembelajaran yang terjadi, akan timbul pemahaman konsep konsep yang terdapat dalam pembelajaran. Pemahaman konsep (Conceptual Understanding) adalah pemahaman yang terintegrasi dan fungsional dari matematika dan ilmu science lainnya, siswa dengan pemahaman konseptual tahu lebih dari fakta yang asing dan metode (Mills, 2016). Menurut Sands (2014), pemahaman konseptual umum digunakan oleh fisikawan serta dalam literatur Pendidikan. Kata 'konseptual'dalam fisika bertolak belakang dengan pendekatan matematika yang kuantitatif, namun pendekatan kualitatif juga tidak berperan kuat dalam pemahaman konseptual. Dari kedua pendapat di atas, menyatakan bahwa konsep pemahaman konseptual muncul dalam ilmu science khususnya fisika serta Pendidikan. Dengan 
pemahaman konseptual akan menemukan pengetahuan yang lebih banyak dan mendalam. Pemahaman konseptual sering muncul dalam Fisika karena banyak mengandung konsep - konsep. Fisika menjelaskan gejala fisik yang terjadi di alam semesta (Diani, 2015). Materi fisika diperlukan bukti nyata agar siswa dapat memahami materi pembelajaran (Astuti et al., 2017). Dalam menjelaskan gejala fisik dan konsep tersebut tidak hanya digunakan kata-kata, namun juga grafik, gambar dan sumber belajar lain serta perumusan matematis dalam menerangkan konsep yang dijelaskan (Respatiningrum et al., 2015). Setiap konsep yang ada saling berkaitan, sehingga jika salah satu konsep tidak di pahami akan berpengaruh pada pemahaman konsep lainnya. Oleh sebab itu diperlukan penekanan penguatan konsep dalam pelajaran Fisika pada mahasiswa. Pemahaman ini juga sering tidak memberikan deskripsi yang benar mengenai hukum fisika. Kesalahan yang mungkin adalah kesalahan konseptual atau miskonsepsi.

Konsep-konsep fisika dalam bidang kelistrikan kebanyakan bersifat abstrak (Hartanto \& Nawir, 2017). Sehingga masih banyak yang mengalami miskonsepsi pada konsep rangkaian listrik. Penelitian yang dilakukan di SMAN 1 Turen menunjukkan sebesar 27,7\% siswa mengalami miskonsepsi listrik dinamis (Budiningsih et al., 2013). Penelitian yang dilakukan di SMA Negeri di kota Cimahi menunjukkan yang berpeluang mengalami miskonsepsi sebesar 39,9\% (Ismail et al., 2015). Jika keadaan konsepsi mahasiswa dibiarkan, hal ini akan menggangu pemahaman dalam mempelajari materi Rangkaian Listrik dan menyebabkan rendahnya kemampuan mereka dalam menyelesaikan persoalan dalam Rangkaian Listrik. Oleh sebab itu, penting bagi mahasiswa sebagai calon guru fisika memahami dan mengerti bagaimana konsep materi fisika itu sendiri secara utuh sebelum mengajarkan ke siswa.

Pada saat ini instrumen yang digunakan untuk mengidentifikasi miskonsepsi materi rangkaian listrik pada mahasiswa yaitu tes diagnostik four-tier berbasis kertas. Perguruan tinggi sudah harus menuju e-campus dengan menyediakan segala layanan pendidikan yang berbasis elektronik (Helaluddin \& Wijaya, 2019). Penggunaan instrumen tes diagnosis miskonsepsi yang berbasis web dianggap sangat cocok dalam era Pendidikan 4.0 yang sangat bergantung pada loT serta era digital ini. Penggunaan instrumen berbasis web juga memberikan keuntungan dalam kecepatan dalam mendiagnosa miskonsepsi mahasiswa. Instrumen berbasis web dapat memberikan hasil tes secara langsung yang dapat dilihat serta datanya dapat disebarkan lebih luas (Suyoso et al., 2017). Instrumen yang telah dikembangkan nantinya akan senantiasa dapat digunakan kapanpun dan dimanapun, hal tersebut sesuai dengan karakteristik web.

Berdasarkan uraian di atas, maka perlu untuk dilakukan penelitian dengan tujuan penelitian ini adalah: (1) untuk mengembangkan instrumen miskonsepsi mahasiswa Pendidikan Fisika berbasis web pada materi Rangkaian Listrik, (2) untuk mengetahui kelayakan hasil pengembangan miskonsepsi mahasiswa Pendidikan Fisika berbasis web pada materi Rangkaian Listrik.

\section{METODE}

Penelitian pengembangan ini menggunakan model analysis, design, development, implementation, and evaluation yang dikenal dengan ADDIE. Prosedur pengembangan yang dibuat berdasarkan tahap-tahap dari model yang digunakan yaitu model ADDIE. Model pengembangan ADDIE milik Rusdi terdiri dari 5 tahap. Prosedur pengembangan instrumen pengukur miskonsespsi berbasis web meliputi analysis (analisis), design (desain), development (pengembangan) dan implementation (implementasi).

Analisis dilakukan dengan melihat penelitian terdahulu pada repositori Universitas Jambi dengan rentang dari tahun 2010-2020. Setelah dihasilkan maka dokumen tersebut dianalisis perkembangan apa saja yang telah dilakukan oleh peneliti sebelumnya untuk dijadikan acuan. 
Tahap desain berupa menentukan tim pengembangan, menentukan sumber daya yang dibutuhkan, menyusun jadwal pengembangan, memilih dan menentukan cakupan, struktur dan urutan materi, pembuatan storyboard, menentukan spesifikasi produk dan menentukan prototype produk.

Jenis data pada penelitian ini adalah data kualitatif dan data kuantitatif. Sumber data untuk data kuantitatif diperoleh dari hasil lembar validasi ahli dan respin penguna pada uji kelompok kecil, sedangkan sumber data kualitatif diperoleh dari lembar validasi yang didalamnya terdapat saran serta komentar validator. Berdasarkan sumbernya, data penelitian dapat dikelompokkan menjadi dua jenis, yaitu data primer dan data sekunder. Data primer adalah data yang diperoleh peneliti secara langsung melalui penyebaran angket validasi ahli.

Dalam penelitian ini instrumen yang digunakan yaitu instrumen angket validasi ahli. Angket validasi ahli digunakan untuk memvalidasi produk. Untuk instrumen angket validasi ini adaptasi dari penelitian sebelumnya yang dilakukan oleh Murya et al., (2013).

Analisis data validasi dilakukan dengan menganalisis butir-butir data validasi sebagai data kuantitatif serta saran dan komentar validator sebagai data kualitatif yang digunakan untuk merevisi produk. Analisis data kualitatif diperoleh dari saran validator pada hasil validasi pengembangan instrumen miskonsepsi mahasiswa pendidikan fisika berbasis web pada materi rangkaian listrik. Adapun cara menganalisis data kualitatif adalah sebagai berikut: (1) pengumpulan data, (2) reduksi, saran dan masukan berupa perbaikan dari setiap validator akan ditulis dalam bentuk teks, (3) penyajian data, data yang telah direduksi kemudian akan disajikan dalam bentuk deskripsi, (4) penarikan kesimpulan dan verifikasi (Rijali, 2018).

Analisis data validasi dan angket respon dilakukan dengan menganalisis butirbutir data validasi dan angket respon yang digunakan untuk merevisi poduk. Data hasil validasi dan angket respon selanjutnya dikuantitatifkan dengan memberikan skor sesuai dengan bobot yang telah ditentukan pada skala likert. Statistik deskriptif adalah statistik yang mempunyai tugas untuk mengumpulkan, mengolah, dan menganalisis data dan kemudian menyajikan dalam bentuk yang baik (Ghozi \& Nunindyo, 2015). Selain itu juga dapat menunjukkan tingkat kelayakan dengan menggunakan persentase kriteria kelayakan sesuai dengan interval yang telah ditentukan pada tabel 1 untuk merevisi produk. Menurut Asyhari \& Silvia (2016), perhitungan persentase didapatkan dari:

$P=\frac{f}{n} \times 100 \%$

Keterangan:

$\mathrm{P} \quad=$ persentase kelayakan

$\mathrm{f} \quad=$ jumlah skor aspek penilaian

$\mathrm{n} \quad=$ jumlah skor maksimal aspek penilaian

Sedangkan kriteria tingkat kelayakan penilaian skor rata-rata dari persentasi tertera pada tabel 1:

Tabel 1. Skala Interpestasi Kerja

\begin{tabular}{cc}
\hline Interval & Kriteria \\
\hline $0 \%-20 \%$ & Sangat Kurang layak \\
$21 \%-40 \%$ & Kurang layak \\
$41 \%-60 \%$ & Cukup layak \\
$61 \%-80 \%$ & Layak \\
$81 \%-100 \%$ & Sangat layak \\
\hline
\end{tabular}

\section{HASIL dan PEMBAHASAN}

\section{Penyajian Data Validasi Ahli}

Hasil dari penelitian ini berupa web yang dapat digunakan untuk mengidentifikasi miskonsepsi pada materi rangkaian listrik melalui four-tier test. Four tier test merupakan suatu alat penilaian untuk menentukan konsepsi siswa. Four-tier test 
memiliki empat tingkatan, yaitu tingkat pertama adalah pertanyaan pengetahuan berupa pilihan ganda, tingkat kedua adalah pertanyaan tentang keyakinan atas jawaban pada tingkat pertama, kemudian tingkat ketiga adalah penyajian alasan jawaban pada tingkat pertama, serta tingkat terakhir adalah pertanyaan tentang keyakinan atas alasan jawaban pada tingkat ketiga. Sebelum diuji coba, instrumen sebelumnya melewati uji validitas desain produk. Uji validitas ini dilakukan dengan dua orang ahli dengan dua kali tahap validasi.

Analisis kuantitatif kelayakan instrumen four-tier test berbasis web pada materi rangkaian listrik menggunakan angket validasi ahli setelah melalui dua tahap validasi menunjukkan hasil menunjukkan pada aspek functionality skala interpestasi kerja sebesar 92,86\%, reability sebesar 91,07\%, usability sebesar 93,06\% dan efficiency sebesar $93,75 \%$ serta rata-rata sebesar $92,68 \%$. Berdasarkan skala interval yang ditunjukkan pada tabel 1 menyatakan bahwa aspek functionality, reability, usability, dan efficiency sangat layak. Sedangkan berdasarkan rata-rata dari setiap aspek menunjukkan bahwa web yang dikembangkan sangat layak untuk mengindentifikasikan miskonsepsi dan pemahaman mahasiswa pada materi rangkaian listrik baik dalam aspek functionality, reability, usability, dan efficiency. Pembelajaran berbasis website berpotensi besar dapat meningkatkan pembelajaran di kelas yang memberikan pengalaman yang luas bagi dosen dan mahasiswa yang sulit ditemukan pada pembelajaran di kelas tradisional (Purmadi \& Surjono, 2016).

Hasil pengembangan instrumen four-tier test materi rangkaian listrik berbasis web dipaparkan sebagai berikut :

1. Halaman home

Akses halaman utama / Home dapat di akses oleh siapa saja. Tampilan pertama berisikan home dengan berbagai menu yaitu, tentang, dan login guru. Pada tampilan awal dibuat semenarik mungkin agar pengguna tertarik dalam menggunakan instrumen fout-tier test materi rangkaian listrik berbasis web.

2. Halaman login

Tampilan di bawah muncul jika menu login yang berisikan sub-menu login mahasiswa dan dosen, selain itu juga terdapat sub menu daftar bagi mahasiswa yang belum terdaftar dalam web.

3. Halaman profil pengembang

Tampilan diatas muncul jika kita mengklik menu tentang yang berisikan profil pengembang berupa identitas pengembang dan akun media social pengembang.

4. Halaman instrumen four-tier test

Tampilan diatas akan muncul setelah mahasiswa login dan mengklik menu uji miskonsepsi pada halaman menu mahasiswa. Tampilan di atas berisikan pengisian identitas mahasiswa saat melakukan uji miskonsepsi materi rangakaian listrik.

5. Halaman hasil mahasiswa

Tampilan diatas akan muncul setelah mahasiswa mengisi halaman uji miskonsepsi yang berisikan pengisian jawaban mahasiswa, skor mahasiswa dan kategori pemahaman pada materi rangakaian listrik.

6. Halaman kategori pemahaman

Tampilan diatas akan muncul setelah dosen login dan mengklik menu grafik pemahaman pada halaman menu dosen. Tampilan di atas berisikan tabel persentase dan grafik pemahaman mahasiswa pada setiap item saat melakukan uji miskonsepsi materi rangkaian listrik.

7. Halaman grafik miskonsepsi

Tampilan diatas akan muncul setelah dosen login dan mengklik menu grafik pemahaman pada halaman menu dosen. Tampilan di atas berisikan tabel persentase dan grafik pemahaman mahasiswa pada setiap item saat melakukan uji miskonsepsi materi rangkaian listrik.

Saran dan perbaikan dari validator I dan validator II adalah sebagai berikut: (1) menambahkan tanggal dan waktu pengerjaan mahasiswa, (2) data yang ditunjukkan dapat di unduh dalam format pdf, (3) penulisan soal disesuaikan dengan 
kaidah yang sesuai, (4) penambahan menu admin. Setelah saran dan perbaikan yang diberikan oleh validator di reduksi maka peneliti selanjutnya melakukan revisi produk. Adapun hasil perbaikan yang dilakukan peneliti adalah sebagai berikut:

1. Penambahan waktu pengerjaan mahasiswa pada menu detail mahasiswa

Setelah mahasiswa selesai mengisi instrument miskonsepsi rangkaian listrik dan menekan tombol kirim maka jawaban mereka akan disimpan sesuai dengan waktu pengiriman mereka dan akan ditunjukkan pada tabel detail mahasiswa.

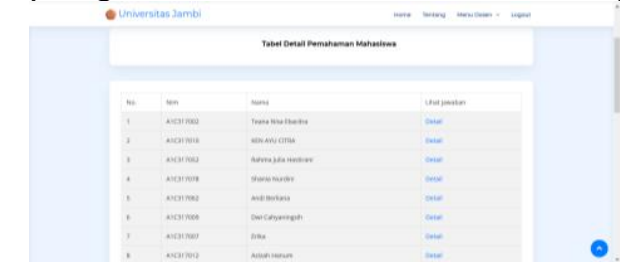

Gambar 1. Menu sebelum direvisi

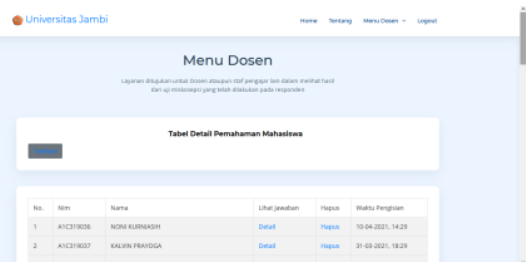

Gambar 2. Menu setelah direvisi

2. Hasil dapat di download dalam format pdf

Hasil pengujian miskonsepsi dapat didownload dalam format pdf sesuai dengan kelas yang diinginkan ataupun seluruh kelas.

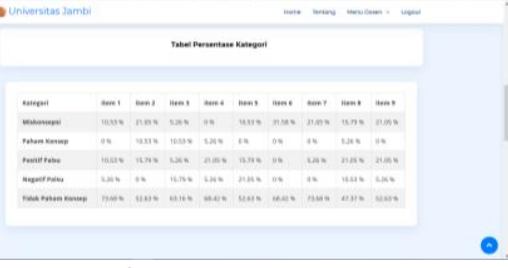

Gambar 3. Sebelum direvisi

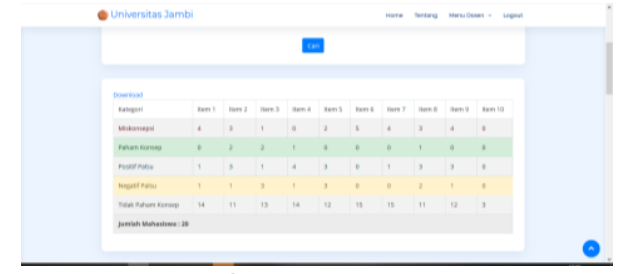

Gambar 4. Setelah direvisi

3. Penulisan intrumen miskonsepsi disesuaikan dengan kaidah

Penulisan instrumen yang mengandung simbol fisika disesuaikan dengan kaidah yang diubah dalam coding yang sesuai dengan simbol tersebut dalam bahasa pemograman.

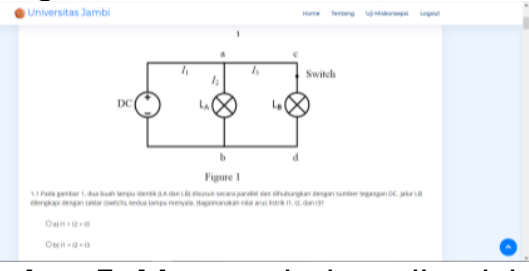

Gambar 5. Menu sebelum direvisi

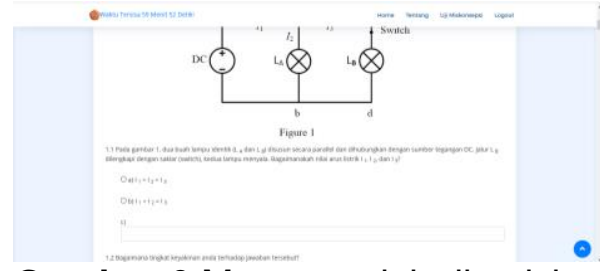

Gambar 6 Menu setelah direvisi

4. Penambahan menu admin

Penambahan menu admin bertujuan untuk memudahkan dosen dalam menggunakan web dan memungkinan admin dalam mengelola web.

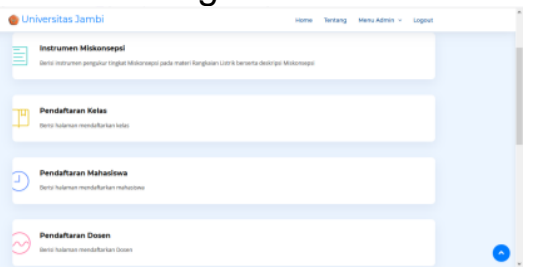

Gambar 7. Penambahan menu admin setelah direvisi

\section{Penyajian Data Uji Kelompok Kecil}

Implementasi pengembangan instrumen miskonsepsi berbasis web materi rangkaian listrik menggunakan aplikasi dreamweaver pada subjek kelompok kecil dengan 17 orang responden Program Studi Pendidikan Fisika yang terdiri dari angkatan 2019. Implementasi dilakukan secara online dengan rentang waktu 31-11 April 2021. Setelah melakukan pengisisan uji miskonsepsi pada materi rangkaian listrik 
responden/pengguna diberi angket respon terhadap penggunaan instrumen miskonsepsi berbasis web pada materi rangkaian listrik melalui google form. Hasil angket respon tersebut merupakan data kuantitatif yang selanjutnya diubah ke data kualitatif. Adapun hasil analisis angket respon yaitu pada aspek materi sebesar $81 \%$, Bahasa $80 \%$, tampilan $79,8 \%$, dan manfaat $81 \%$. Pada kateogori Bahasa dan manfaat tergolong lama sangat layak sedang kan Bahasa dan tampilan dikatakan layak. Berdasarkan data hasil di atas, maka dapat diperoleh skor rata-rata sebesar 3,22 dengan kategori baik atau dengan persentase kelayakan sebesar 80,05\% dengan kategori layak sehingga dapat disimpulkan bahwa pengembangan instrumen miskonsepsi berbasis web pada materi rangkaian listrik dapat diterima oleh pengguna.

Untuk mengetahui miskonsepsi yang dimiliki mahasiswa maka dibutuhkan pengukuran. Pengukuran miskonsepsi yang dilakukan saat ini menggunakan instrumen miskonsepsi berbasis kertas. Dengan berkembangnya teknologi memberikan pengaruh dalam Pendidikan. Salah satu pengaruh tersebut adalah perlalihan tes berbasis kertas (PBT) menjadi tes berbasis computer (CBT). CBT memiliki keunggulan dibandingkan dengan PBT yaitu (1) meningkatkan standardisasi, (2) meningkatkan keamanan tes, (3) meningatkan kemampuan tampilan tes, (4) memperkecil error of measurement, dan (5) mempercepat pemberian skor dan interpretasi (Suhardi, 2018)

Salah satu bentuk penerapan CBT adalah four-tier test berbasis web yang dapat digunakan melalui computer maupun telepon untuk mengidentifikasikan miskonsepsi. Penggunaan instrumen miskonsepsi mahasiswa Pendidikan fisika berbasis berbasis web pada materi rangkaian listrik dapat diakses melalui link http://fteci.Ims-merdeka.com. Dengan itu akan menampilkan yang berisikan menu home, tentang, dan login. Home berisikan informasi dan penjelasan mengenai web dan four-tier test. Menu tentang berisikan profil dan informasi tentang pengembang. Sedangkan menu login berisikan halaman login yang terdiri atas login mahasiswa, login dosen dan login admin.

Instrumen miskonsepsi berbasis web pada materi rangkaian listrik akan memudahkan dosen dalam mengidentifikasikan miskonsepsi dan pemahaman konsep yang dimiliki mahasiswa. Hal ini dapat ditunjukkan dengan kecepatan dalam menghasilkan pengelompokkan pemahaman dan miskonsepsi mahasiswa sesuai dengan interpretasi dan deskripsi miskonsepsi. Pada pengidentifikasian yang dilakukan secara manual maka harus dicari terlebih dahulu satu per satu item per tier, kemudian dicocokan dengan interpresasi four tier, dan deskripsi miskonsepsi dihitung kemudian yang akan dijadikan grafik. Sementara dengan menggunakan instrumen miskonsepsi berbasis web maka tidak membutuhkan waktu yang lama dalam mengolahnya.

\section{KESIMPULAN}

Dari proses dan hasil peneitian ini, peneliti dapat mengambil kesimpulan: (1) Penelitian ini menghasilkan instrument four-tier test berbasis web pada materi rangkaian listrik yang ditujukkan bagi dosen dan mahasiswa yang dapat digunakan dalam mengindentifikasikan miskonsepsi yang timbul pada mahasiswa dengan cepat dapat mengelompokan konsepsi dan miskonsepsi berdasarkan interprestasi dan deskripsi miskonsepsi, (2) penelitian ini hanya mengembangkan instrument four-tier test berbasis web pada materi rangkaian listrik yang ditujukkan bagi dosen dan mahasiswa, (3) pengembangan instrumen four-tier test pada materi rangkaian listrik berbasis web ini berdasrakan validasi ahli memperoleh nilai persentase rata-rata kelayakan $92,67 \%$ dan berdasarkan uji kelompok kecil sebesar $80,05 \%$. Instrumen ini dinyatakan sangat layak untuk mengidentifikasikan miskonsepsi pada materi rangkaian listrik. 


\section{DAFTAR RUJUKAN}

Astuti, I. A. D., Sumarni, R. A., \& Saraswati, D. L. (2017). Pengembangan Media Pembelajaran Fisika Mobile Learning berbasis Android. JPPPF - Jurnal Penelitian \& Pengembangan Pendidikan Fisika, 3(1), 57-62. https://doi.org/10.21009/jrpk.072.10

Asyhari, A., \& Silvia, H. (2016). Pengembangan Media Pembelajaran Berupa Buletin dalam Bentuk Buku Saku untuk Pembelajran IPA Terpadu. Jurnal IImiah $\begin{array}{llll}\text { Pendidikan Fisika } & \text { Al-Biruni, } & 5(1), & 1 .\end{array}$ https://doi.org/10.24042/jpifalbiruni.v5i1.100

Budiningsih, S., Muhardjito, M., \& Asim, A. (2013). Pengembangan Intrumen Diagnostik Three-Tier Untuk Mengidentifikasi Miskonsepsi Listrik Dinamis Siswa Kelas X SMA. Universitas Negeri Malang.

Diani, R. (2015). Pengembangan Perangkat Pembelajaran Fisika Berbasis Pendidikan Karakter dengan Model Problem Based Instruction. Jurnal IImiah Pendidikan Fisika Al-Biruni, 4(2), 243. https://doi.org/10.24042/jpifalbiruni.v4i2.96

Fitria, A. (2014). Miskonsepsi Mahasiswa Dalam Menentukan Grup Pada Struktur Aljabar Menggunakan Certainty of Response Index (CRI) di Jurusan Pendidikan Matematika IAIN Antasari. Jurnal Pendidikan Matematika, 1(2), 45-60. https://doi.org/10.18592/jpm.v1i2.50

Ghozi, S., \& Nunindyo, A. (2015). Statistif Deskriptif Untuk Ekonomi. Deepublish.

Hartanto, T. J., \& Nawir, M. (2017). Terhadap Konsep Rangkaian Listrik Arus Searah ( Direct Current ). Jurnal Vidya Karya, 32(2), 97-109.

Helaluddin, \& Wijaya, H. (2019). Pengembangan Kompetensi Pendidik Di Perguruan Tinggi dalam Menyosong Era Revolusi Industri. Ekplolrasi Sumberdaya Alam Hayati Indonesia Indonesia Berbasis Enterpreneurship Di Era Revolusi Industri 4.0, 1-6.

Hilma, L., Asma, L., \& Thriwaty, A. (2017). Pengembangan Nilai Karakter dan Kecakapan Hidup Bagi Santri Ndalem di Pondok Pesantren Roudlotul Jannah Kabupaten Kudus. Solidarity: Journal of Education, Society and Culture, 6(1), $1-10$.

Inah, E. N. (2015). Peran Komunikasi Dalam Interaksi Guru Dan Siswa. Al-Ta'dib, 8(2), $150-167$.

Ismail, I. I., Samsudin, A., Suhendi, E., \& Kaniawati, I. (2015). Diagnostik Miskonsepsi Melalui Listrik Dinamis Four Tier Test. Prosiding Simposium Nasional Inovasi dan Pembelajaran Sains, 2015(Snips), 381-384.

Mills, S. (2016). Conceptual Understanding: A Concept Analysis. The Qualitative Report, 21(3), 546-556. https://nsuworks.nova.edu/tqr/vol21/iss3/8

Murya, Y., Ardhana, K., Utami, E., \& Luthfi, E. T. (2013). Sistem Informasi Geografis Berbasis Android Sebagai Media Informasi Pariwisata Di Kabupaten Banyumas. Teknologi Informasi, 8(24), 1-21.

Purmadi, A., \& Surjono, H. D. (2016). Pengembangan Bahan Ajar Berbasis Web Berdasarkan Gaya Belajar Siswa Untuk Mata Pelajaran Fisika. Jurnal Inovasi Teknologi Pendidikan, 3(2), 151. https://doi.org/10.21831/jitp.v3i2.8285

Respatiningrum, N., Radiyono, Y., \& Wiyono, E. (2015). Analisis Miskonsepsi Materi Fluida pada Buku Ajar Fisika SMA. Jurnal Prosiding Seminar Nasional Fisika dan Pendidikan Fisika, 6(1), 313-317.

Rijali, A. (2018). Analisis Data Kualitatif. Alhadharah: Jurnal IImu Dakwah, 17(33), 8195. https://doi.org/10.18592/alhadharah.v17i33.2374

Sands, D. (2014). Concepts and Conceptual Understanding: What Are We Talking About? NDIR, 10(1), 7-11. https://doi.org/10.11120/ndir.2014.00030

Subekti, H., Taufiq, M., Susilo, H., Ibrohim, I., \& Suwono, H. (2017). Mengembangkan Literasi Informasi Melalui Belajar Berbasis Kehidupan Terintegrasi Stem Untuk Menyiapkan Calon Guru Sains Dalam Menghadapi Era Revolusi Industri 4.0: Revieu Literatur. Education and Human Development Journal, 3(1), 81-90. https://doi.org/10.33086/ehdj.v3i1.90 
Suhardi, I. (2018). Kajian Deskriptif Perbandingan Model Pengujian Paper Based Test dan Computer Based Test (Tinjauan Dari Aspek Psikometrik, Konteks dan Suasana Serta Psikologi Pengguna). Jurnal Media Komunikasi Pendidikan Teknologi dan Kejuruan, 5(2), 61-70.

Suyoso, S., Subroto, S., \& Istiyono, E. (2017). Pelatihan KIT Alat Fluida Bergerak Untuk Guru SMA/MA di Daerah Istimewa Yogyakarta. Pengapdian Masyarakat MIPA dam Pendidikan Mipa, 1(1), 12-16.

Utomo, S. S. (2019). Guru Di Era Revolusi Industri 4.0. Format Pendidikan Untuk Meningkatkan Daya Saing Bangsa, 1(1), 1-13. 